\title{
Mellom kunnskapsdiskurs og sosial diskurs: Ukeplaner som sjanger og vurderingspraksis
}

Tidsskriftet Sakprosa

Bind 10, Nummer 2

(C) 2018 


\section{Sammendrag}

Denne artikkelen undersøker ukeplanen slik den brukes og forstås i kommunikasjonen mellom skole og hjem i barneskolen i Norge. Vi ser ukeplanen som en type funksjonell sakprosa som er svært utbredt, og analyserer hvordan sjangeren ukeplan er utformet, hvilke funksjoner den fyller, og hvordan den posisjonerer barn og foresatte i forhold til skolens vurderingsarbeid. Analysen omfatter 34 ukeplaner samlet inn fra 12 skoler med spredning i geografi og klassetrinn. Ukeplanene er utpreget multimodale tekster, og utformingen analyseres i form av meningsklynger som danner mønstre av obligatoriske og valgfrie elementer. Basert på kritisk diskursanalyse undersøkes ukeplanen som en sjanger som gjør elever og foresatte til medansvarlige i skolens læringsarbeid. Analysen viser to delvis konkurrerende diskurser, en som handler om skolens kunnskapssyn og en sosial diskurs som handler om fellesskap og tilhørighet. På bakgrunn av en drøfting av forholdet mellom disse to slik de fremkommer i ukeplanene, diskuterer vi hvilke ideologiske føringer som ligger til grunn, og her viser vi først og fremst til New Public Management som styringsideologi.

\section{Abstract}

In this article we examine the weekly schedule as an important part of the communication practice between school and home arena in Norwegian primary school. We consider the weekly schedule a widespread type of functional nonfictional text, and analyse how this genre is formed, what functions it fills, and how it positions children and parents when it comes to assessment in school. The analysis consists of a total of 34 weekly schedules collected from 12 schools that are dispersed in geography and grades. These weekly schedules are distinctly multimodal texts, and the design is analysed on basis of clusters of meaning that forms patterns of obligatory and optional items. Based on critical discourse analysis the weekly schedule is examined as 
a genre that makes pupils and parents jointly responsible for learning outcomes and learning strategies in school. The analysis shows that the weekly schedules reflect two partly competing discourses; a discourse about the school's understanding of knowledge, and a social discourse about fellowship and belonging. On basis of how these two discourses appear in the weekly schedules, we discuss the ideological context that influence the genre, above all New Public Management as management ideology.

Nøkkelord: Ukeplan, meningsklynger, skole-hjem-samarbeid, lekser, vurderingspraksis, læringsmål, New Public Management.

\section{Om forfatterene:}

Gro-Renée Rambø er professor ved Institutt for nordisk og mediefag, Fakultet for humaniora og pedagogikk, Universitetet i Agder. Elise Seip Tønnessen er professor ved Institutt for nordisk og mediefag, Fakultet for humaniora og pedagogikk, Universitetet i Agder. 


\section{Mellom kunnskapsdiskurs og sosial diskurs: Ukeplaner som sjanger og vurderingspraksis}

\section{Introduksjon}

Ukeplaner er en type sakprosa som alle med ansvar for barn i skolen kjenner til. Dette er funksjonell sakprosa som spiller en sentral rolle i kommunikasjonen mellom skole og hjem. I denne artikkelen konsentrerer vi oss om planene på trinn 1-7, som henvender seg til både elever og foresatte. Ukeplanene (som også kalles arbeidsplan, lekseplan, ukebrev) inngår i en klart definert og regelmessig kommunikasjonspraksis mellom lærere og elever, og mellom skole og hjem, og utgjør ryggraden i det daglige samarbeidet. Det er denne regelmessigheten som gjør at vi har fattet interesse for å undersøke ukeplanen som sjanger. Vi forstår da «sjanger» i nyretorisk forstand, som en tekstnorm som har vokst fram gjennom regelmessig bruk for å fylle funksjoner i en spesifikk sosial praksis (Miller, 1994). Ukeplanene har en institusjonell forankring som virker inn på utformingen når lærerne lager dem, og styrer forventningene når elever og foreldre leser dem (Todorov, 1990, s. 18). Tilknytningen til skolen som samfunnsinstitusjon gjør det også interessant å undersøke hva slags diskurser om kunnskap og læring som blir representert i disse ukeplanene, og hvilke relasjoner de forutsetter eller skaper mellom lærere, elever og foresatte.

Ukeplanene kan ses som en videreutvikling av tidligere lekseplaner, som ga oversikt over ukas hjemmearbeid. Lekseplanene hadde først og fremst en informativ og regulerende funksjon, og hadde som hovedhensikt å gi elevene oversikt over ukas arbeid. At foreldrene dermed kunne sette seg inn i hva barna holdt på med i skolehverdagen, var i første omgang en bifunksjon. Etter 
hvert har lekseplanene blitt utvidet med andre elementer av relevans for skole-hjem-relasjonen. Vår studie har ikke materiale til å undersøke sjangerens historiske utvikling, men så langt vi har klart å bringe på det rene, førte læreplanreformen Kunnskapsløftet (LKo6; Utdanningsdirektoratet, 2006) til en vending i denne ukentlige kommunikasjonen med hjemmene. Med LKo6 ble læreplanene i sterkere grad målstyrt, og det førte til et behov for å kommunisere læringsmålene tydelig til både elevene og deres foresatte. Dagens ukeplaner inngår dermed i skolens daglige design av elevenes læringsarbeid, og vi har særlig fattet interesse for sjangeren fordi vi ser at den de senere årene har utviklet seg fra primært å gi informasjon til også å fylle en sentral funksjon i skolens jevnlige vurderingsarbeid. Denne funksjonen vil vi belyse og diskutere kritisk.

Vi vil altså analysere hvordan ukeplanene er utformet, hvilke funksjoner de fyller, og hvordan de posisjonerer barn og foresatte i forhold til skolens vurderingsarbeid og overordnede verdier.

For å svare på de to første spørsmålene vil vi undersøke ukeplanen som sjanger ved først å beskrive hvilke elementer som inngår i et utvalg ukeplaner og se om vi finner noen faste mønstre, og deretter drøfte kritisk hvilke funksjoner de fyller. I noen tilfeller vil vi også kommentere om ukeplanene forandrer seg etter hvert som elevene blir eldre, derfor har vi valgt å se på et utvalg ukeplaner fra 2., 5. og 7. trinn for hver av de utvalgte skolene. For å svare på det siste spørsmålet vil vi se nærmere på den overordnede sosiale konteksten ukeplanen inngår i. Vi vil her se på hvordan systematiske trekk i ukeplanene kan sies å gjenspeile ideologiske perspektiver knyttet til samfunnsdiskursen om skole og læring. 


\section{Tidligere forskning}

Ukeplanene er tekster som ikke har påkalt mye interesse fra forskere, kanskje fordi de er så hverdagslige at de går under radaren. Tilgrensende forskning som kan belyse konteksten for vår tekstnære studie, kan finnes innenfor en pedagogisk tradisjon. Der har man blant annet vært opptatt av kommunikasjon i samarbeidet mellom skole og hjem, og av en vurderingspraksis som kommuniserer elevenes ansvar for egen læring.

I Danmark har forskere ved Universitetet i Århus (DPU) foretatt en litteraturgjennomgang av forskning på foreldresamarbeid i et inkluderingsperspektiv (Røn Larsen, 2014), der de peker på dilemmaer ut fra utdanningssosiologiske perspektiv. De konkluderer blant annet med å peke på noen områder som er mangelfullt utforsket, for eksempel foreldresamarbeidets betydning for barns og familiers hverdagsliv (s. 53) og konsekvensene av at stadig mer av kommunikasjonen foregår gjennom digitale medier (s. 54).

Den norske pedagogen Thomas Nordahl (2007) har interessert seg for kommunikasjonen mellom skole og hjem mer allment, og omtaler tre nivåer: informasjon, dialog og medbestemmelse/medvirkning. Informasjon omtaler han som enveiskommunikasjon, mens det er først på det andre nivået at kommunikasjonen reelt sett kan få dialogisk karakter, slik at informasjonsutvekslingen går begge veier. Reelt samarbeid finner han først på det tredje nivået, der hjemmet får mulighet til å være med å bestemme og medvirke i utformingen av elevens skolegang. Nordahls forskning er fulgt opp i to norske masterprosjekt, som undersøker kommunikasjonen fra foreldrenes perspektiv (Møller-Nilsen, 2011) eller sammenholder lærer- og foreldreperspektivet (Gundersen, 2014). Begge konkluderer med at økt informasjonsmengde ikke uten videre bidrar til reell dialog mellom skole og hjem. Tidligere forskning tyder altså på at den typen regelmessig kommunikasjon vi ønsker å under- 
søke, stort sett er enveis informasjon fra skolen til hjemmet, som viderefører innarbeidede roller og maktfordeling.

Ser man på ukeplanene som et læringsverktøy, kan forskning på vurderingspraksiser, og særlig de som tar sikte på at elevene selv skal vurdere og regulere sin læring, gi relevant bakgrunn for å drøfte ukeplanenes pedagogiske funksjon (Hopfenbeck, 2011). Innenfor en pedagogisk diskurs har fokus også vært på hvordan arbeidsplaner (et begrep som delvis brukes synonymt med «ukeplaner», men oftest på høyere klassetrinn) kan brukes for å fremme tilpasset opplæring (Bergem \& Dalland, 2010a, 2010b; Klette, 2007a, 2007b). Vurdering er tett knyttet til læringsmål og måloppnåelse. I prosjektet «Forskning på individuell vurdering i skolen» (FIVIS) defineres ukeplaner som «et verktøy som skal gi informasjon til eleven og foreldre/foresatte om det tilsiktede læringsresultatet» (Sandvik et al., 2012, s. 74), og resultatene fra prosjektet viste at elever på alle trinn i norsk grunn-skole hadde relativt høy bevissthet om vurdering, noe som blant annet knyttes til ukeplanenes tydelige læringsmålfokus (Sandvik \& Buland, 2014, s. 121).

Vårt prosjekt har sitt utgangspunkt i kritisk tekstforskning og har som mål å se på ukeplanene som funksjonell sakprosa. Et slikt tekstkritisk perspektiv finner vi i Anna Annerbergs (2016) doktoravhandling om svenske gymnaslæreres skrivepraksis. Annerberg undersøker svenske gymnaslæreres skrivepraksis innenfor rammen av kritisk diskursanalyse (CDA) og New Literacy Studies, og trekker blant annet inn digitaliseringen i skole og samfunn. Til tross for stor variasjon mellom lærerne finner hun noen felles diskursive vilkår for slik skriving. Av særlig relevans for vår studie er at lærerne tilstreber legitimitet og effektivitet, de gjenbruker tekster og maler, særlig i digital skriving. Det er særlig to strategier som anvendes for å sikre legitimitet: å behandle elevene likt og å låne autoritet fra skolemyndighetene (s. 283). Annerberg viser at lærerne er mottakerorienterte i sin skriving, og at de opplever en potensiell konflikt mellom ulike mottakere, plassert som de er i 
hierarkiet mellom skoleledelse og elever/foreldre. Når de skriver sine vurderinger («omdömen»), skriver de på den ene siden for eleven, men på den andre siden skal teksten også fungere som dokumentasjon for en gransking fra overordnede (s. 288). Slike spenninger kan også være relevante i vår analyse av ukeplanene, selv om den tekstpraksisen vi studerer, er særegen for de yngste elevene. Vi setter primært søkelyset på hvordan ukeplanene fungerer som kommunikasjon til elever og foreldre, men Annerbergs gjennomgang av vilkårene for lærernes skrivepraksis kan bidra til vår forståelse for tekstenes form og funksjon.

\section{Teoretiske perspektiver}

I vår analyse ser vi på ukeplanene som tekster som inngår i en kommunikativ eller tekstlig praksis mellom skole og hjem. Gjennom regelmessige gjentakelser danner de forventninger og konvensjoner for hvordan teksten er utformet, og hvilke funksjoner den fyller i denne konkrete kommunikasjonskonteksten. Det er slike konvensjoner som danner grunnlaget for å snakke om en sjangernorm. Vi er også interessert i å se på ukeplanene som en konkretisering av skolens plass i samfunnet. Skolens tekster inngår i en diskursiv orden («order of discourse»), et nettverk av sosiale praksiser slik de kommer til uttrykk gjennom språk og tekster (Fairclough, 2003, s. 24). Et viktig aspekt å belyse er hvilke stemmer som kommer til uttrykk i teksten. Tekster kan uttrykke en mer eller mindre personlig stemme, og denne stemmen vil være avgjørende for hvor forpliktende en forstår det som sies, og for hvilken verdi den representerte virkeligheten tilskrives (Fairclough, 2003, s. 164). Hvem sin stemme det er som kommer fram, er sentralt for å kunne avdekke ideer, verdier og holdninger som teksten er preget av på ulike nivåer (Fairclough, 2010, s. 9).

Kritisk diskursanalyse ser på tekster som på en gang representasjoner av en sosial virkelighet og interaksjon innenfor den samme virkeligheten. Norman 
Fairclough støtter seg til et funksjonelt syn på språk og tekster, der tekster kan forstås ut fra flere funksjonelle aspekt, eller som Fairclough foretrekker å uttrykke det: «types of text meaning» (Fairclough, 2003, s. 27), som veves sammen i ethvert utsagn. De meningstypene som Fairclough legger vekt på i diskursanalysen, er handling knyttet til sjanger, representasjon av ulike diskurser eller aspekter ved virkeligheten, og identifikasjon, som knytter sosiale og personlige bånd mellom deltakerne ved hjelp at tekstens stil.

Faircloughs kritiske diskursanalyse gir først og fremst gode redskaper til å analysere skriftlige tekster. Ukeplanene som vi studerer, er utpreget multimodale tekster som tar i bruk bilder, piktogrammer, logoer og ulike typer tabelloppsett og maler som meningsbærende ressurser. I slike tekster er altså også den visuelle utformingen meningsbærende, slik at både spatial utforming og plassering sier noe om hvordan mening formidles. I en integrert analyse av det multimodale uttrykket har vi funnet det fruktbart å operere med meningsklynger som analyseenhet (Baldry \& Thibault, 2006; Kvåle, 2012). En klynge («cluster») kan bestå av ulike semiotiske ressurser som er gruppert sammen ved hjelp av innramming eller avstand til andre elementer på arket. Slik utgjør de «a small-scale functional arrangement of items included in some larger scale arrangement» (Baldry \& Thibault, 2006, s. 31).

Hvordan meningsklyngene plasseres inn i en helhetlig komposisjon, kan også være styrt av innarbeidede vaner og konvensjoner. I sin visuelle designgrammatikk opererer Gunther Kress og Theo van Leeuwen (2006) med en horisontal og en vertikal akse. Langs den horisontale aksen anvender tekstprodusenter og lesere innarbeidede konvensjoner for leseretning, slik at kjent informasjon gjerne plasseres til venstre, mens ny informasjon legges til mot høyre. Tilsvarende definerer de en vertikal akse, der overordnet informasjon gjerne blir plassert øverst, og mer konkret og utfyllende informasjon nederst. I tillegg påpeker de at informasjon kan være ordnet ut 
fra en sentrum-periferi-dimensjon, slik at det mest sentrale plasseres i midten.

I vår analyse vil vi først drøfte ukeplanene som tekstlig praksis ut fra Faircloughs tre typer mening, og deretter drøfte hvordan denne praksisen kan ses som uttrykk for sosiale strukturer og verdier.

\section{Metode}

Til undersøkelsen har vi hentet inn ukeplaner fra tolv skoler. For å sikre bredden i utvalget har vi valgt ut seks skoler i Oslo, geografisk spredd i byen, fire skoler i en forholdsvis stor bykommune i en annen landsdel, og to skoler $\mathrm{i}$ en landkommune. Dette utvalget gir ikke grunnlag for å undersøke forskjeller relatert til størrelsen på kommunen eller skolen, men det sikrer oss mot at materialet blir ensidig preget av praksiser som kan utvikle seg innenfor en administrativ enhet eller et geografisk avgrenset område. Utvalget bygger altså på et strategisk utvalg av kommuner, og et stratifisert utvalg av skoler innenfor disse kommunene, ved at vi sikret oss en spredning mellom bydeler. Innenfor disse rammene er utvalget tilfeldig. Fra hver skole har vi tatt med ukeplaner for trinn 2, 5 og 7 (én av skolene dekker bare trinn 1-4 og er representert med bare 2. trinns ukeplan). Det gir oss muligheter til å se på fellestrekk innenfor én skole, eller innenfor én aldersgruppe. Vi ønsket å analysere ukeplaner fra en «normaluke» og valgte ut uke 39, 2017, da skolen var godt i gang etter sommeren, og før den ble preget av spesielle aktiviteter nærmere jul. I noen få tilfeller har det ikke vært mulig å få tak i denne planen, og da har vi erstattet den med planen for en annen uke etter samme kriterier.

Vi tok kontakt med skolene via rektor for å få tillatelse til å bruke materialet i forskning. De fleste ukeplanene er tilgjengelige digitalt, med eller uten passordbeskyttelse. Skolene fikk skriftlig informasjon om prosjektet og ble 
forsikret om at eventuelle navn eller andre personidentifiserende opplysninger ville bli slettet eller sladdet før materialet ble lagret og analysert.

Som grunnlag for analysen gjennomførte vi først en kartlegging av hvilke meningsklynger ukeplanene besto av, for å svare på spørsmålet om hvordan sjangeren ukeplan er utformet. Slik fikk vi en systematisk oversikt over hele materialet, og kunne si noe om hva som var faste bestanddeler i ukeplanene, og hva som var variable elementer. Deretter analyserte vi materialet som uttrykk for en diskursiv orden ut fra Faircloughs (2003, s. 27) tre meningstyper. I analysen av handling la vi særlig vekt på hvilke kommunikasjonshandlinger tekstene utfører. I planenes representasjon av skolevirkeligheten så vi etter gjennomgående diskurser i planene og la særlig vekt på hvilke fag og læringsmål som framheves. I analysen av identifikasjon la vi vekt på hvilke stemmer som kommer til uttrykk i teksten, og hvordan den henvender seg til elever og foreldre (Fairclough, 2003, s. 164). Til sammen kan disse tre dimensjonene vise hvilke funksjoner ukeplanene fyller, og legge grunnlaget for å belyse det siste spørsmålet i vår problemstilling, som forutsetter at vi ser ukeplanene i sammenheng med de sosiale strukturene de inngår i, når vi spør hvordan de posisjonerer barn og foresatte iforhold til skolens vurderingsarbeid og overordnede verdier. Her vil vi ta utgangspunkt i skolediskursen på samfunnsplan og vurdere nærmere hvordan konkurrerende diskurser framhever ulike verdier og plasserer ansvar og makt hos ulike aktører.

\section{Ukeplanenes utforming: Mønster og variasjon i en diskursiv orden}

Oversikten over meningsklyngene vi har identifisert i de 34 ukeplanene som inngår i analysen (se tabell 1), viser at noen meningsklynger er helt grunnleggende for sjangeren: Overskriften og en eller annen form for oversikt over timer, emner og arbeidsoppgaver (lekser) går igjen i alle ukeplanene. Vi vil også regne læringsmål og beskjeder fra skolen (som finnes i henholdsvis 33 og 32 av 34 planer) som grunnleggende for sjangeren. Disse meningsklyngene 
legger stor vekt på det informative, og de innebærer enveiskommunikasjon fra læreren til elever og foresatte. Slik befinner kommunikasjonen seg på Nordahls (2007) laveste nivå. Den viderefører tradisjonen fra tidligere tiders timeplaner og lekseplaner, og konstituerer en tydelig rollefordeling der lærerne har kontroll over kunnskap og arbeidsformer, og elever og foresatte har behov for informasjon. Vi vil gå nærmere inn på disse sentrale meningsklyngene i en mer detaljert analyse nedenfor.

\begin{tabular}{|c|c|c|c|c|}
\hline Meningsklynge & $\begin{array}{l}\text { 2. trinn } \\
\mathrm{N}=12\end{array}$ & $\begin{array}{l}\text { 5. trinn } \\
\mathrm{N}=11\end{array}$ & $\begin{array}{l}\text { 7. trinn } \\
\mathrm{N}=11\end{array}$ & $\begin{array}{l}\text { Totalt } \\
\mathrm{N}=34\end{array}$ \\
\hline \multicolumn{5}{|l|}{$\begin{array}{l}\text { 1.Fatisk kommunikasjon: tilhørighet/ } \\
\text { identitet }\end{array}$} \\
\hline overskrift & 12 & 11 & 11 & 34 \\
\hline tegning & 6 & 0 & 0 & 6 \\
\hline bilde av skolen & 2 & 2 & 3 & 7 \\
\hline $\log 0$ & 6 & 5 & 6 & 17 \\
\hline valgspråk & 3 & 1 & 3 & 7 \\
\hline hilsen & 9 & 7 & 3 & 19 \\
\hline \multicolumn{5}{|l|}{ 2. Mål og planer } \\
\hline mål for uka & 11 & 11 & 11 & 33 \\
\hline time/emne/lekseplan & 12 & 11 & 11 & 34 \\
\hline ukas øveord & 6 & 4 & 3 & 13 \\
\hline gloser & 2 & 7 & 8 & 17 \\
\hline ukas begreper/bokstav & 5 & 5 & 3 & 13 \\
\hline gruppeinndeling & & 1 & 1 & 2 \\
\hline elevens egenvurdering & 1 & 2 & 3 & 6 \\
\hline \multicolumn{5}{|l|}{ 3. Praktisk info/kommunikasjon } \\
\hline beskjeder & 11 & 10 & 11 & 32 \\
\hline beskjeder fra AKS/SFO & 2 & & & 2 \\
\hline navnefelt & & & 1 & 1 \\
\hline kvittering fra foresatte & 1 & 1 & 2 & 4 \\
\hline kontaktinfo & 9 & 8 & 8 & 25 \\
\hline digitale lenker & 3 & 4 & 1 & 8 \\
\hline \multicolumn{5}{|l|}{ 4. Sosialt } \\
\hline bursdager & 1 & & & 1 \\
\hline diverse arrangement utenfor skoletid & 1 & 1 & 1 & 3 \\
\hline sosiale mål (spesifisert separat) & 2 & 2 & 2 & 6 \\
\hline
\end{tabular}

Tabell 1: Oversikt over meningsklynger. Oppsummering av meningsklyngeanalyse av 34 ukeplaner fra 12 skoler, 2. 5. og 7. trinn. Tabellen er i hovedsak ordnet i den rekkefølgen meningsklyngene opptrer i i ukeplanene 
Av meningsklynger som finnes i minst halvparten av ukeplanene, finner vi skolens logo i 17 ukeplaner. En logo har som hovedfunksjon å skape gjenkjennelse og identifikasjon. I sju ukeplaner ser vi at et fotografi av skolen har samme plassering og trolig fyller noe av samme funksjon. Like mange har tatt med skolens valgspråk, og i noen tilfeller er dette plassert sammen med logoen. I eksempelet øverst til høyre i figur 3 er elementer fra skolens logo (her dekket til av personvernhensyn) brukt til å ramme inn en annen logo, som viser til en større satsing skolen deltar i. PALS (NUBU, 2017) er en innsatsmodell som står for «positiv atferd, støttende læringsmiljø og samhandling». Slik knyttes skolens identitet til en mer omfattende satsing med klare ideologiske overtoner.

Videre har halvparten av ukeplanene en liste over gloser som skal læres denne uka, vanligvis knyttet til engelskfaget. Tretten av ukeplanene har et eget felt for ukas øveord, som oftere er knyttet til norskfaget. Det er også ukas bokstav, som vi finner i noen av ukeplanene for andre trinn. På alle trinn finner vi også eksempler på ukas begreper, som kan være hentet fra ulike fagfelt.

Ser vi gloser, øveord og begreper under ett, framhever nesten alle ukeplanene lister over enkeltord som elevene skal øve seg på, uten at ukeplanen gjør tydelig rede for hva slags sammenheng disse ordene inngår i. Det er grunn til å tro at disse listene gir indikasjoner på hva som skal testes i ukentlige målprøver (se Flaten \& Vollan i dette nummeret). De aller fleste ukeplanene (25) inneholder også kontaktinformasjon til skolen, slik som telefonnummer eller e-postadresser. Ofte er denne informasjonen koplet til konkrete beskjeder om hvordan en kan melde om fravær ved å sende en standardisert tekstmelding. Endelig inneholder 19 av de 34 ukeplanene en verbal hilsen fra lærerne. Denne er oftest plassert mot slutten av ukeplanen og representerer en sosial avrunding.

De meningsklyngene som bare finnes i et mindretall av ukeplanene, oppfatter vi som valgmuligheter som lærerne legger til etter ønske eller behov. Slik 
bidrar de til å vise en variasjonsbredde innenfor sjangeren og definerer lærernes handlingsrom. Seks av planene har en tegning plassert i samme område som logo og overskrift. Den er gjerne av typen som man kan hente ut av et digitalt arkiv (clip art), og den kan markere årstid eller tilknytning til et barnefellesskap (se eksempler øverst til venstre og nederst til høyre i figur 3). I de tilfellene der vi har hatt tilgang til planene fra ukene før den vi har undersøkt, ser vi at dette er elementer som kan ligge fast som del av headingen på ukeplanene, i alle fall for en periode. Slike tegninger finner vi bare i planene for 2. trinn, og vi ser dem som et element som primært henvender seg til elevene, som gjennom den første leseopplæringen er vant til å ha bilder som støtte til skrift (Tønnessen \& Vollan, 2010). Tegningene har som hovedfunksjon å skape en felles forståelse av aktiviteter og læringstema og presentere det på en hyggelig måte.

Seks av ukeplanene har egne felt der elevene blir bedt om å vurdere sin egen læring. Her skal de krysse av for om de har oppnådd ukas læringsmål.

Eksempelet i figur 1 går igjen med samme oppsett, men ulike målformuleringer på alle trinnene vi har undersøkt på den aktuelle skolen. Slik framstår dette som en mal som gir uttrykk for skolens praksis med å utfordre elevene til egenvurdering i skolearbeidet sitt.

\begin{tabular}{|l|l|l|}
\hline \multicolumn{1}{|c|}{ Læringsmål: } & Kan noe & Kan godt \\
\hline Norsk: Jeg vet hva en elling er & & \\
\hline Engelsk: Jeg kan si navnet på 6 farger på engelsk & & \\
\hline Matte: Jeg kan regne minus med tall mellom 0 og 20 & & \\
\hline Sosialt: Jeg sitter fint på stolen min & & \\
\hline
\end{tabular}

Figur 1: Oppsett av læringsmål der eleven skal vurdere sin egen måloppnåelse i to trinn. Oppsettet finnes på alle trinn; dette eksempelet er hentet fra 2. trinn 
I andre tilfeller er det de foresatte som gjøres ansvarlige for oppfølging av hjemmearbeid. I eksempelet i figur 2 er dette knyttet til lekser i ulike fag, der vi leser rubrikken for at leksene er «sett», som henvendt til de foresatte.

\begin{tabular}{|c|c|c|}
\hline Fag & Lekse & Sett \\
\hline$\underbrace{2}_{\text {Norsk }}$ & $\begin{array}{l}\text { Les totalt } 100 \text { minutter i en selvvalgt bok i løpet av uken. I de ni rutene } \\
\text { kan du selv skrive inn hvor mye du har lest. Pass på at det blir minst } 100 \\
\text { min i løpet av uken. La noen hjemme signere på at leksen er gjort i den } \\
\text { store ruten i bunn av tabellen. }\end{array}$ & \\
\hline & $\begin{array}{l}\text { Gjør ferdig side } 47 \text { og } 49 \text { i Multi. Vi jobber litt med disse på skolen også! } \\
\text { Det er gode forklaringer på side } 46 !\end{array}$ & \\
\hline Engelsk & $\begin{array}{l}\text { Les s. 24-25 Skriv et kort sammendrag om hva filmen handlet om. } \\
\text { Skriv og læer deg glosene. }\end{array}$ & \\
\hline Samfunnsfag & $\begin{array}{l}\text { Les sidene } 60 \text { - } 64 \text { i Globus samfunnsfag. } \\
\text { Teksten handler om ti vitenskapsmenn. Du skal finne ut hva de heter, hva } \\
\text { de fant opp eller oppdaget og når de levde. } \\
\text { Altså: HVEM, HVA og NÅR. } \\
\text { Du velger selv hvordan du løser oppgaven, men skriv i samfunnsfag } \\
\text { skrive bok eller på PC. }\end{array}$ & \\
\hline Finn ut av! & $\begin{array}{l}\text { Skriv svarene dine i norsk skrivebok! } \\
\text { 1. Hvorfor sitter ikke edderkopper fast i sitt eget nett? } \\
\text { 2. Hvilke ingredienser er i en berlinerbolle? }\end{array}$ & \\
\hline
\end{tabular}

Figur 2: Eksempel på lekseplan med eget felt for kvittering fra foresatte

Dette eksempelet er hentet fra 7. trinn, og denne ukeplanen har ikke mindre enn fire slike responsfelt: I tillegg til oversikten over fag og lekser som er vist i figur 2, finner vi en oversikt over læringsmål der eleven skal vurdere sin egen innsats i to trinn, ett felt der foresatte skal skrive under på at «arbeidsplanen er sett», og et «lesekort for uken», der det skal registreres hva som er lest hjemme, med signatur. I denne ukeplanen er det også laget et felt der eleven skal skrive sitt navn, noe som kan tyde på at dokumentet skal leveres tilbake til skolen med alle kvitteringene på at arbeidet er gjort og vurdert. Disse meningsklyngene er de eneste som inviterer til (eller krever) toveiskommunikasjon omkring ukeplanene, men siden responsen stort sett er 
avgrenset til å fylle ut en forhåndsdefinert rubrikk, vil vi ikke kalle kommunikasjonen dialogisk i Nordahls (2007) forstand.

I en del av ukeplanene er det lagt inn digitale lenker som viser til andre tekster, i åtte tilfeller som frittstående meningsklynger, i andre tilfeller som del av andre klynger. De kan være integrert i lekseplanen og vise til læringsressurser på internett, eller det kan være lenker til mer overordnet skoleinformasjon, for eksempel om nasjonale prøver. Slik kan disse lenkene knytte ukeplanen til nasjonale ressurser og strategier, samtidig som de indikerer at ukeplanene i mange tilfeller distribueres digitalt.

En siste gruppe av meningsklynger som bare finnes sporadisk i ukeplanene, handler om det sosiale livet i klassen eller nærmiljøet. Det kan være oversikt over hvem som har fødselsdag den aktuelle uka, eller henvisninger til ulike arrangement som foregår utenfor skoletid. Her har vi også plassert noen få tilfeller der sosiale mål er framhevet med egne meningsklynger, i motsetning til de fleste av ukeplanene, der de er plassert sammen med læringsmålene.

\section{Handling: Meningsklyngenes kommunikative funksjon}

I tabell 1 har vi gruppert meningsklyngene i fire grupper etter hvilke hovedfunksjoner vi ser at de fyller i kommunikasjonen mellom hjem og skole. Figur 3 viser et eksempel på første side av en ukeplan, der vi har markert to typer meningsklynger med rammer i farger som viser eksempler på grupperingen. 


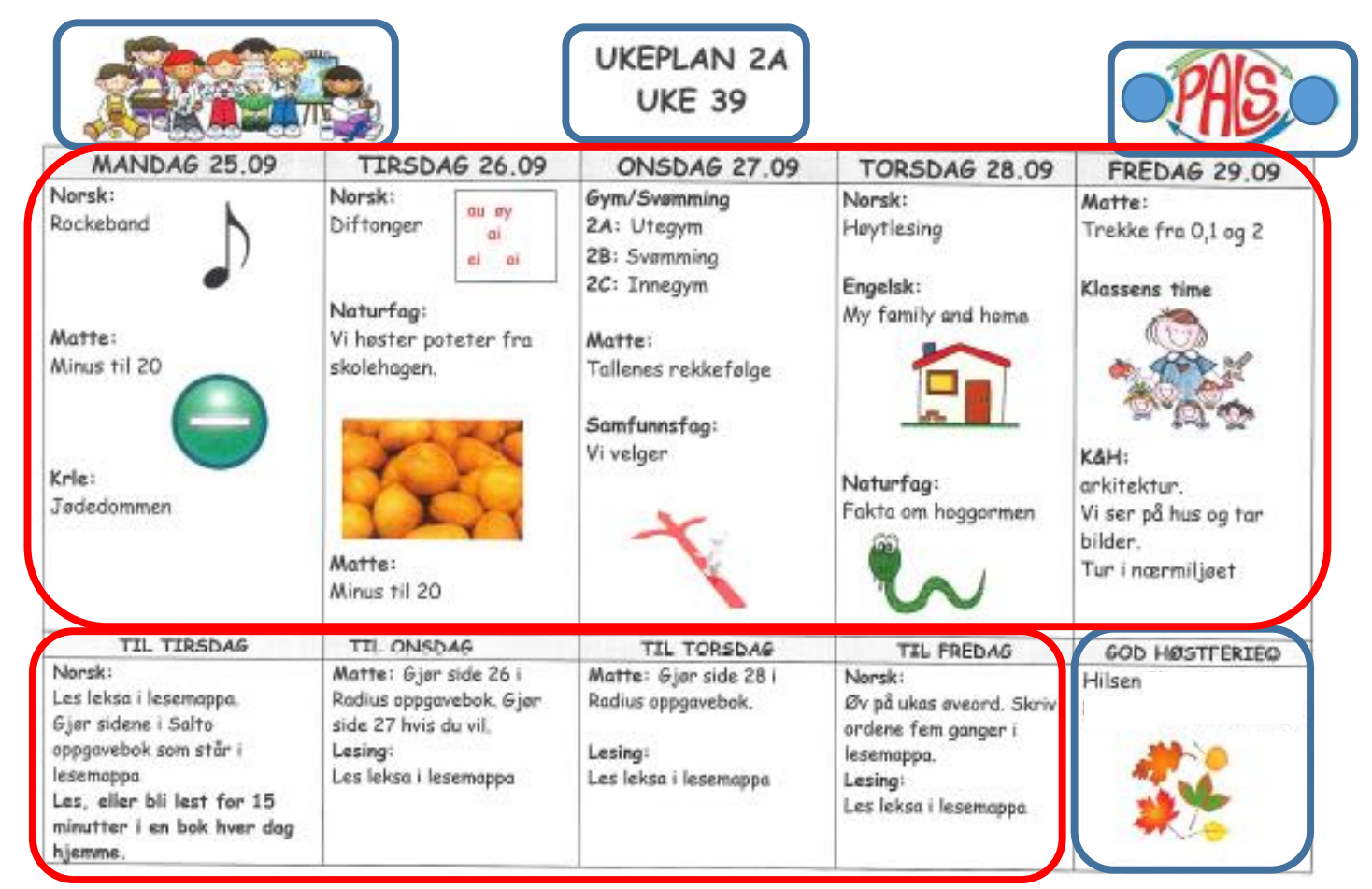

Figur 3: Eksempel på første side av en ukeplan for 2. trinn. Vi har satt inn blå rammer, som markerer meningsklynger som skaper kontakt med leserne, og røde rammer, som markerer sentral informasjon i ukeplanene. På s. 2 finnes beskjeder, mål for uka, øveord og begreper

De fire kommunikasjonsfunksjonene vi finner representert i vårt materiale, er 1) fatisk kommunikasjon som understreker tilhørighet og identitet, 2) kunnskapsorientert informasjon om mål, time- og lekseplaner, 3) praktisk informasjon om skolens daglige virksomhet og 4) informasjon om det sosiale livet i og rundt skolen. Siden den siste gruppa bare finnes sporadisk i vårt materiale, konsentrerer vi oss her om fellestrekk ved de tre første kategoriene.

Den første gruppa meningsklynger har som hovedfunksjon å bygge identitet og tilhørighet gjennom gjenkjennelse. Den har altså primært en relasjonsbyggende funksjon, som tar sikte på å plassere avsendere (lærerne/skolen) og mottakerne (elever og foresatte) innenfor samme fellesskap. Den består stort 
sett av elementer som er plassert øverst på ukeplanarket, en posisjon som uttrykker overordnede verdier («the ideal») i Kress og van Leeuwens (2006, s. 197) visuelle designgrammatikk. Bare ett element, hilsen fra lærerne, har en annen plassering, nemlig mot slutten av ukeplanen. Slik ser vi at relasjonsbyggende elementer rammer inn de meningsklyngene som er mer informative i sin funksjon.

Den andre gruppa gir informasjon som er sentral for skolens læringsaktivitet, som mål, timeplan og lekser. Slik informasjon kan framstå som tilbud, eller som krav, sier Fairclough (2003, s. 108). Flere av meningsklyngene vi har identifisert, innebærer krav om at mottakerne skal handle etter dem. Det gjelder leksene, som skal utføres, og målene, som skal oppnås. Slik vil mål-formuleringene innebære et krav, selv om dette bare i noen tilfeller er eksplisitt uttrykt med krav om at eleven eller de foresatte skal kvittere på at kravet er oppfylt. Målformuleringene er ofte plassert først i denne gruppa av meningsklynger, og da får de en overordnet verdi som premissleverandør for den konkrete organiseringen av timer og arbeidsoppgaver. I andre tilfeller er de plassert etter time- og lekseplan, eller integrert i dem, noe som peker mot et mer dynamisk og dialogisk forhold mellom mål og arbeidsoppgaver, der målene fungerer som begrunnelse for arbeidet som skal utføres.

I den tredje gruppa meningsklynger, som gir praktisk informasjon om skolens aktiviteter og om kontakt, er det også den informative funksjonen som dominerer. Disse er gjennomgående plassert etter mål, timeplan og lekser, og blir dermed framstilt som mindre viktige eller grunnleggende for skolens virksomhet. De kan innebære krav, for eksempel krav om å gi skolen beskjed om fravær, men også tilbud om informasjon og kontakt, og påminnelser som hjelper elever og foreldre å gjennomføre skolehverdagen. 


\section{Representasjon: Hvordan skolens verden framstilles}

Diskursivt gir disse meningsklyngene en representasjon av hva skolen skal være, og hvordan den fungerer i samfunnet. Meningsklyngene, slik vi har gruppert dem ovenfor, gir ikke nødvendigvis et entydig bilde av livet i skolen. Vi ser særlig to konkurrerende diskurser: Den første gruppa av meningsklynger representerer primært skolen som et fellesskap bundet sammen av sosiale bånd og felles mål. Dette vil vi kalle den sosiale diskursen. Den andre gruppa representerer det vi kan kalle kunnskapsdiskursen. Den gir primært informasjon om læringsarbeidet ved skolen, og sier dermed noe om hva skolene anser som viktig kunnskap.

I oversikten over målformuleringer er det visse fag som går igjen (se tabell 2). Norsk, matematikk og engelsk topper listene med målformuleringer, og de kommer vanligvis i den rekkefølgen. Denne klare prioriteringen av læringsmål viser en slags back to basics-diskurs i skolenes formulering av læringsmål. Samtidig kan de sentrale fagene norsk og matematikk også knyttes til grunnleggende ferdigheter som muntlige ferdigheter, lesing, skriving og regning. I en neste pulje prioriteres målformuleringer innenfor det som tidligere ble samlet i betegnelsen «orienteringsfag»: naturfag, samfunnsfag og kristendom, religion, livssyn og etikk (KRLE). Her ser vi en tendens til at målene i disse fagene framheves mer på 5. og 7. trinn enn på 2. trinn, i samsvar med at faginndelingen blir tydeligere på mellomtrinnet. I noen tilfeller ser vi en kopling mellom naturfag og samfunnsfag, ved at de er plassert i en felles linje i tabelloppsett eller liste. De fagene som sjelden blir synliggjort med målformuleringer, er de praktisk-estetiske fagene. Derimot har de fleste skolene framhevet sosiale mål, plassert enten først eller sist på lista. Disse er noe mer framtredende tidlig i skolegangen. 


\begin{tabular}{|l|c|c|c|c|}
\hline Fag & $\begin{array}{l}2 . \text { trinn } \\
\mathrm{N}=12\end{array}$ & $\begin{array}{l}\text { 5. trinn } \\
\mathrm{N}=11\end{array}$ & $\begin{array}{l}\text { 7. trinn } \\
\mathrm{N}=11\end{array}$ & $\begin{array}{l}\text { Totalt } \\
\mathrm{N}=34\end{array}$ \\
\hline Norsk & 12 & 11 & 11 & 34 \\
\hline Matematikk & 12 & 11 & 10 & 33 \\
\hline Engelsk & 10 & 11 & 10 & 31 \\
\hline Naturfag & 7 & 8 & 10 & 25 \\
\hline Samfunnsfag & 4 & 8 & 8 & 20 \\
\hline KRLE & 5 & 7 & 7 & 19 \\
\hline Musikk & 2 & 2 & 2 & 6 \\
\hline Kunst og håndverk & 2 & 1 & 2 & 5 \\
\hline Kroppsøving & 1 & 1 & 2 & 4 \\
\hline Sosialt & 9 & 7 & 7 & 23 \\
\hline
\end{tabular}

Tabell 2: Oversikt over hvilke fag målformuleringene er knyttet til, fordelt på 2., 5. og 7. trinn

\section{Identifikasjon: Henvendelse og ansvarliggjøring}

Ukeplanene kan invitere mottakerne til å identifisere seg med teksten på ulike måter. Fairclough peker på to dimensjoner (2003, s. 75, med henvisning til Brown og Gilman, 1960): Den ene dimensjonen dreier seg om makt, som kan komme til uttrykk i form av sosiale hierarkier. Den andre dimensjonen dreier seg om solidaritet eller sosial avstand.

I det foregående har vi beskrevet ukeplanene som dominert av enveiskommunikasjon, der skolen og lærerne står som avsendere. Det kan virke uklart om det er skolen som institusjon eller den enkelte klasselærer som kommuniserer, og dette får konsekvenser for både makt- og nærhetsrelasjoner. Den første gruppa meningsklynger i vår analyse var preget av kommunikasjon som har som funksjon å etablere og vedlikeholde en relasjon. Når ukeplanene bruker skolens logo og valgspråk, framhever det relasjonen til skolen som institusjon. Men læreren har også et visst handlingsrom til å bygge en personlig relasjon, gjennom valg av tegninger, bruk av farger, og en personlig hilsen, der de gjerne bruker fornavn. Dette bygger ned det institusjonelle preget og skaper nærhet. I samme retning trekker den siste gruppa av meningsklynger, der vi ser sporadiske innslag av informasjon om 
sosiale hendelser i og rundt klassen. Disse står i kontrast til de sentrale meningsklyngene, som informerer om mål og planer og gir praktisk informasjon. Her ser vi lite til lærernes personlighet, mens skolens faglige og målstyrte arbeid står i fokus.

Mottakerne i ukeplanenes kommunikasjon er elever og foreldre, og vi finner det særlig interessant å undersøke hvordan de tiltales, og hvordan de direkte eller indirekte gjøres ansvarlige for å oppnå skolens mål. Her vil vi særlig konsentrere oss om pronomenbruk i målformuleringene og lekseplanene. Det er gjennomgående at det er eleven som er adressat for de meningsklyngene som handler om læringsmål - for eksempel uttrykkes dette språklig gjennom bruk av første persons personlig pronomen «jeg», som i «Jeg kan alle tiervennene» (2. trinn, skole 12). Andre person finner vi særlig i beskjedene om lekser som er uttrykt i imperativ («Gjør ferdig», «Skriv og lær», se figur 2). Dermed er disse beskjedene henvendt direkte til elevene. Det skaper nærhet, samtidig som imperativformen viser et maktforhold der læreren har rett til å bestemme over elevenes arbeid, mens de foresatte får en mer distansert kontrollfunksjon. Imidlertid framkommer det ofte indirekte, særlig for de laveste trinnene (2. trinn i vår undersøkelse), at også foresatte er adressat for disse meningsklyngene. Det kan for eksempel framkomme i selve avkryssingsfeltet for vurdering av måloppnåelse, der det kan stå «Jeg vet hva en elling er» (skole 10), når det i en annen meningsklynge som er myntet på foresatte, forklares hva en elling er for noe. Det er videre rimelig å anta at når det gjelder de laveste trinnene, vil elevene være avhengige av en lesekyndig person for å avkode selve teksten, siden mange elever ikke vil ha oppnådd en så solid ortografisk lesekompetanse ennå at de kan lese teksten alene. Tredje persons instrukser («Elevene må lese hver dag!») er tydelig henvendt til foreldrene og understreker deres medansvar for å følge opp barnas hjemmearbeid.

På sjuende trinn finner vi også ett eksempel på at tiltaleformen varierer mellom fag («Du skal kunne», «Eleven skal kunne» og «Jeg kan»), noe som 
tyder på at hver faglærer har valgt sin form. Dermed brytes den institusjonelle helheten på avsendersiden opp i ulike fagdiskurser.

Hovedmønsteret for målformuleringene er altså at de uttrykkes i første person: «Jeg kan ...» (se f.eks. figur 1). Slik blir skolens læringsmål lagt i munnen på eleven, som gjøres ansvarlig for å nå dem. Det krever en omskriving av læringsmålene til en uttrykksmåte elevene kan identifisere seg med. Vi finner eksempler på særlig «skolske» uttrykksmåter, slik som i dette målet for matematikk på andre trinn: «Jeg kan regne med ensifrede tall ved å hoppe på tallinje.» Her kan selve begrepsbruken i læringsmålene ikke sies å samsvare med det en kan regne som rimelig å forvente at en 2.-klassing har tilgang til. For eksempel kan en lure på om 2.-klassingen vet hva dette læringsmålet betyr: «Jeg kan dele tosifrede tall i tiere og enere. Jeg kan regne addisjon med ensifrede tall med tierovergang.» Dette er uttrykk for et akademisert språk. Selv om læringsmålet inneholder en eksemplifisering («9 $+8=9+1+7=10+7=17 »)$, forutsetter forståelsen temmelig avansert kunnskap (2. trinn, skole 9). Dette betyr at selv der hvor vi ikke kan finne noen stemme i teksten som åpenbart har foresatte som adressat, så tilsier konteksten at de må ses som adressat på lik linje med eleven. Slik ansvarliggjøres også foresatte for læringsmålene i ukeplanen. Til tross for førstepersonsformen kan slike diskursblandinger føre til sosial distanse, særlig i hjem som ikke har et nært forhold til skolens mål.

I noen meningsklynger er relasjonene ikke synlige, det gjelder listene med ukas ord, gloser og begreper. Vi tolker mangelen på forklaring og sammenheng som at disse listene underforstått henviser til praksisen med målprøver ved slutten av uka. Slik underforstått kommunikasjon kan komme til å skape skiller mellom mottakere som er godt kjent med skolens praksis, og de som ikke er det. Samlet sett gjenskaper ukeplanene hierarkiske relasjoner der skolen og lærerne representerer samfunnets mål og verdier for utdanningen, 
mens elevene og de foresatte blir plassert i en posisjon der de skal gjennomføre dette i praksis. Det skal vi drøfte nærmere i neste del.

\section{Skolens diskursive orden som uttrykk for sosial praksis}

Ukeplanen som sjanger inngår som en sentral del av skolens tekstlige praksis (Fairclough, 2003, s. 24). Denne tekstlige praksisen kan igjen ses på som en del av en overordnet sosial praksis. Siden alle tekster inngår i en kontekst, kan en gjennom tekstanalyse også gi mulige forklaringer på hva som kan være det ideologiske grunnlaget for valgene som blir gjort på det tekstlige nivået. Sjangeranalysen har vist at ukeplanen har to hovedfunksjoner: Den er viktig for det sosiale ved skole-hjem-samarbeidet og søker å bygge relasjoner og fellesskapsfølelse. Samtidig presenterer ukeplanene informasjon om arbeid som skal gjøres og læringsmål som skal oppnås - også på måter som innebærer klare krav til hjemmet. Kombinasjonen av disse to funksjonene bidrar overordnet sett til å trekke hjemmet inn i skolens læringsprosjekt. Som vi har pekt på i sjangeranalysen, kan disse to hovedfunksjonene ses som uttrykk for to delvis konkurrerende skolediskurser: en kunnskapsdiskurs, som først og fremst er rettet mot det faglige innholdet i skolen som undervisningsinstitusjon, og en sosial diskurs, som handler om skolen som et viktig sosialt fellesskap bundet sammen av relasjoner og felles mål. Disse to diskursene samsvarer godt med det Utdanningsdirektoratet har sagt om samarbeid mellom hjem og skole: «Et godt samarbeid mellom hjem og skole er viktig for å legge til rette for læring og trivsel» (Udir, 2016a).

Vi vil i det følgende drøfte funnene fra sjangeranalysen på et overordnet nivå ved å se nærmere på hva som vektlegges innenfor hver av de to diskursene, og også hvordan kunnskapsdiskursen og den sosiale diskursen posisjoneres i forhold til hverandre. Dette kan si noe om underliggende verdier og forutsetninger. Her vil vi drøfte hvilke diskurser ukeplanen er påvirket av, og hvilke 
diskurser den selv påvirker, slik at maktstrukturer og ideologiske føringer kommer til syne (Fairclough, 2010).

\section{Kunnskapsdiskursen}

Den offentlige skolediskursen i Norge har det siste tiåret i stor grad handlet om den dreiningen som har skjedd i nyliberalistisk retning, der styringsformen New Public Management (NPM) har stått sentralt. Innenfor et slikt styringsregime, der det sentrale tankegodset bygger på markedsøkonomiske prinsipper, står mål- og resultatstyring sentralt. Et prinsipp som har fått stor tyngde, er prinsippet om accountability - alle instanser i utdanningssystemet skal stå ansvarlig for resultater som leveres. Spesielt vesentlig på nasjonalt nivå er de nasjonale prøvene i fagområdene lesing, regning og engelsk. Informasjon fra disse prøvene skal danne grunnlag for underveisvurdering og kvalitetsutvikling på alle nivåer i skolesystemet. Denne dreiningen i norsk skolesektor (som i offentlig sektor for øvrig) har skjedd i tråd med internasjonale krefter. OECD står bak de såkalte PISA-testene (Udir, 2016b). Disse internasjonale testene, som gjennomføres hvert tredje år, har som ambisjon å teste 15-åringers kompetanse på ulike fagområder, spesielt lesing, matematikk og naturfag. De er designet for å kunne sammenligne og rangere deltakerlandene og studere endringer over tid, og de har fått stor betydning for kunnskapsdiskursen i norsk skole, både gjennom hva som måles, og selve måten kunnskap og ferdigheter måles på.

I ukeplanene vi har undersøkt, er det for alle trinn meningsklynger som dreier seg om mål og planer (læringsmål for uka, time-/emne-/lekseplaner og tilknyttede oppgaver) som er den mest sentrale meningsklyngetypen (type 2, tabell 1). Siden skolen er en læringsinstitusjon, er det ikke noe påfallende ved at ukeplanen inneholder mye informasjon av denne typen. Derimot er det interessant å se nærmere på hva slags vektlegging av ulike fag ukeplanene gir uttrykk for, og hva slags type lærings- og kunnskapssyn som framkommer 
gjennom den informasjonen som gis, og den diskursen informasjonen inngår i.

Alle ukeplanene i vårt materiale inneholder læringsmål og lekseoversikt knyttet til fagene norsk, matematikk og engelsk (med unntak for 7. trinn ved skole 10, som ikke har læringsmål knyttet til matematikk den aktuelle uka, men som derimot har prøve i dette faget), mens det for alle andre fag er slik at det varierer hvorvidt det oppgis læringsmål og lekser for disse i ukeplanen. Dermed kommuniserer ukeplanene asymmetri når det gjelder viktighet: norsk, matematikk og engelsk anses som de viktigste fagene. Dette er et trekk ved ukeplanene som tydelig er påvirket av samfunnsdiskursen, hvor det er nettopp disse fagene som har status som kjernefag - og som testes på nasjonalt og internasjonalt nivå. Det er også et annet trekk ved ukeplanene som er påfallende, og det er hva slags type kunnskap læringsmålene vektlegger. Det som går igjen, er det en kan kalle faktabasert punktkunnskap. Denne typen kunnskap kjennetegnes ved at den enkelt kan måles og evalueres gjennom tester. Eksempelet nedenfor er hentet fra 2. trinn ved skole 12 og er typisk for læringsmålklyngen i materialet vårt:

\begin{tabular}{|l|l|}
\hline LAERINGSMÅL & \\
\hline Norsk & $\begin{array}{l}\text { Jeg kan lese og skrive ukas øveord. } \\
\text { Jeg kan skrive «jeg-setninger». }\end{array}$ \\
\hline Matte & Jeg kan alle tiervennene. Jeg kan telle opp til 50. \\
\hline Engelsk & $\begin{array}{l}\text { Jeg kan kjenne igjen ordene: mum, dad, brother, sister, familiy. Jeg kan fortelle hva } \\
\text { ordene betyr, og bruke dem i en setning. }\end{array}$ \\
\hline Øveord & Skal, være, ut, to, noe \\
\hline Begreper & Regel, å stemme, å mene, enig, uenig, demokrati \\
\hline
\end{tabular}

Figur 4: Eksempel på ukeplanoppsett for læringsmål. Eksempelet er hentet fra ukeplan for 2. trinn, og oppsettet er typisk for ukeplanene i vårt materiale

Her kan en si at «diskursstemmen» fra offentlige myndigheter trer tydelig fram, siden læreplanene for hvert fag i grunnskolen gjennomgående er bygd 
opp etter målstyring i tråd med NPM-prinsipper, som her. Særlig tydelig blir stemmen til norske utdanningsmyndigheter der hvor læringsmålformuleringene i ukeplanene er hentet direkte fra læreplanen i det aktuelle faget. I læreplanen i matematikk for 2. trinn, som gjelder for meningsklyngen over, er det et kompetansemål innenfor området «Tall» som sier at eleven skal kunne «telle til 100, dele opp og bygge mengder opp til 10, sette sammen og dele opp tiergrupper opp til 100 og dele tosifrete tall i tiere og enere». Læringsmålet i matematikk ovenfor er dermed en direkte konkretisering av dette overordnede målet, men er delt opp i mindre biter (Udir, 2006). Slike oppdelinger i mindre kunnskapsbiter er gjennomgående i ukeplanene de synliggjør forskyvningene fra overordnede nivåer i kunnskaps- og ansvarskjeden til lavere nivåer (jf. modell i Kvåle, 2018), og kan ses på som lærerens legitimering av egen praksis. Samtidig bidrar denne oppstykkingen av overordnede læringsmål i læreplanen til å formidle et bestemt kunnskapssyn. Det handler om «rene» fakta, og det er først og fremst det som kan telles og måles, som er verdifullt. Det er imidlertid ikke bare læreren som ansvarliggjøres gjennom læringsmåloppsettene. Både hjemmet (foreldre/foresatte) og eleven selv blir tillagt plikter og ansvar, som vi har vist $\mathrm{i}$ analysen av identifikasjonsdimensjonen.

Ukeplanene i vårt materiale er fra uke 39 i 2017. Senere denne høsten ble nasjonale prøver for 5 . trinn gjennomført i norsk skole. De fleste skolene retter fokus mot nasjonale prøver enten i læringsmåloppsettene, i ukeplanoppsettene eller i begge. 
Slik ser læringsmåloppsettet i ukeplanen for 5. trinn ved skole 11 ut:

\begin{tabular}{|l|l|}
\hline & Læringsmål \\
\hline Norsk & Jeg vet hvor jeg finner øveoppgavene til nasjoanle prøver i norsk. \\
\hline Engelsk & Jeg vet hvor jeg finner øveoppgavene til nasjoanle prøver i engelsk. \\
\hline Matte & Jeg vet hvor jeg finner øveoppgavene til nasjoanle prøver i matte. \\
\hline
\end{tabular}

Figur 5: Oppsettet gir eksplisitt uttrykk for at det å kunne finne øveoppgavene til nasjonale prøver i de nevnte fagene er et mål for selve læringen. Slike formuleringer er ikke uvanlige i ukeplanene vi har undersøkt, selv om de sjelden står oppført som læringsmåloppsett slik som her (trykkfeilen «nasjoanle» er original)

Dette kan ses på som et svært direkte uttrykk for målstyringsinnflytelsen. Faglig spesifisert kunnskap nevnes ikke i det hele tatt, det er det å finne og øve på oppgaver som gis i nasjonale prøver, som er ukas læringsmål i disse fagene.

Læringsmåloppsettene henger tett sammen med timeplanoppsettene, og også med meningsklyngetypen praktisk informasjon/kommunikasjon (meningsklyngetype 3, tabell 1). Disse klyngene inneholder mange ulike stemmer, og de involverer og ansvarliggjør flere aktører for læringsarbeidet, slik som i dette oppsettet hentet fra ukeplanen for 2. trinn ved skole 12:

Vi øver på å logge inn på datamaskiner på skolen, og på [nettsted]. Elevene har fått personlig «Feide-bruker». Brukernavnet kan de fleste, men passordet er det mange som roter litt med. Passordet er som følger: [anonymisert] (Dvs. [anonymisert] dersom du har bursdag [anonymisert]). Alle brukernavn begynner med [anonymisert], deretter navn og ev. et tall på slutten (eks: [anonymisert]). Fint om dere hjemme også øver på å logge inn på Salaby. 
Her ansvarliggjøres både læringsfellesskapet på skolen («vi», dvs. lærer og elever), elevgruppa («elevene»), deler av elevgruppa («de fleste», «mange»), eleven selv direkte («du»), foreldre/foresatte («dere hjemme»). I noen tilfeller inneholder utsagn både direkte adressat og indirekte adressat på den måten at den direkte adressaten gjøres ansvarlig for å innlemme en indirekte adressat. Et slikt eksempel kan vi finne i et timeplanoppsett hvor det heter: «Snakk om bildet s. 6. 'I can see a ...' sammen med en voksen i 10 min.» (2. trinn, skole 9). Den åpenbare adressaten for utsagnet er eleven, men eleven făr ansvaret for også å ansvarliggjøre noen i hjemmet.

Overordnet sett kan en si at meningsklyngene som først og fremst er uttrykk for kunnskapsdiskursen om norsk skole (meningsklyngetypen vi har kalt Mål og planer i tabell 1, og til dels også meningsklyngetypen Praktisk informasjon/kommunikasjon), åpenbart er preget av mål- og resultatstyringens logikk. Makt forskyves ovenfra og ned i et styringshierarki, der overordnede nasjonale målformuleringer brytes ned til håndterbare biter, og der aktørene på de laveste nivåene - elev og foresatte - gjøres ansvarlige for måloppnåelsen knyttet til enkeltbitene. På nivået over er det læreren, som er den som konkret har formulert innholdet i ukeplanene, som har ansvaret for måloppnåelsen, men stemmen fra offentlige nasjonale og internasjonale instanser definerer mulighetsrommet som læreren kan formulere seg innenfor, og dermed kan formuleringene ses på som en legitimering av lærerens egen praksis - og i noen grad også skolens praksis. Men ukeplanene er ikke bare et tekstlig uttrykk for en kunnskapsdiskurs - de er også uttrykk for en sosial diskurs. Denne har andre ideologiske trekk.

\section{Den sosiale diskursen}

Skolen har både et faglig og et sosialt mandat. I den norske skolens formålsparagraf står det at skolen, i samarbeid med hjemmet, skal gi elevene historisk og kulturell innsikt og forankring, og at opplæringen skal bygge på 
grunnleggende verdier som respekt for menneskeverd og natur, for åndsfrihet, nestekjærlighet, likeverd, solidaritet, at opplæringen skal bidra til innsikt i kulturelt mangfold og fremme demokrati, likestilling og vitenskapelig tenkemåte, og at elevene skal få utviklet kunnskap, ferdigheter og holdninger for å kunne mestre eget liv og kunne delta i arbeid og fellesskap i samfunnet (opplæringsloven, § 1-1). Disse formuleringene gjennomsyrer også lærerprofesjonens etiske plattform (Lærerprofesjonens etiske råd, 2016). Siden ukeplanen er et sentralt bindeledd mellom skole og hjem, er det derfor interessant å se nærmere på hvordan disse aspektene ved den sosiale diskursen om skolen framkommer her.

I sjangeranalysen så vi at meningsklyngetype 1 (Fatisk kommunikasjon, tabell 1) hadde en relasjonsbyggende funksjon ved å bygge identitet og tilhørighet mellom hjem og skole. Disse klyngene rammer som oftest inn ukeplanen ved å være plassert først og sist, og kan slik sies å uttrykke overordnede verdier som omgir resten av meningsinnholdet (Kress \& van Leeuwen, 2006, s. 197). I alle tilfeller hvor skolen har en logo, spiller denne på overordnede idealer som er i tråd med hovedinnholdet i opplæringsloven, § 1-1: ord som «trivsel» og «vekst» og tegninger som uttrykker mangfold og glede, går igjen. Den sosiale diskursen kan også gjenfinnes som sosialt læringsmål i meningsklynger som handler om læringsmål, og i klynger med praktisk informasjon til hjemmet (type 3, tabell 1). I de tilfellene hvor ukeplanen inneholder sosiale læringsmål, kan vi gjenfinne to hovedtyper læringsmål: oppdragerorienterte mål og relasjonelle mål. De oppdragerorienterte sosiale målene er i stor grad behavioristisk orientert - de handler først og fremst om hvordan elevene skal oppføre seg, og har slik et tydelig atferdsmodifiserende element. Slike finner vi på alle trinnene i vår undersøkelse: «Jeg rydder stille når læreren sier ifra» (2. trinn, skole 11), «Jeg møter presis og er forberedt til timen» (2. og 5. trinn, skole 9), «Jeg oppfører meg fint og hører etter når læreren snakker» (7. trinn, skole 10). I alle tilfeller er målene formulert i presens og i første person entall («jeg»), og framstår slik som pålagte krav som eleven er direkte ansvarliggjort 
for og selv må evaluere. Relasjonelle aspekter har også et tydelig fokus i ukeplanene vi har studert. Som sosiale mål finner vi for eksempel: «Jeg er en god venn» (2., 5. og 7. trinn, skole 12), «Jeg er en god fadder, og sørger for at faddergruppen min får en fin tur» (5. trinn, skole 10), «Jeg reflekterer og tenker over hva mobbing kan føre med seg for den som blir utsatt» (7. trinn, skole 11), «Jeg tar hensyn til andre» (7. trinn, skole 9). Ideologisk sett kan en si at denne siste typen er uttrykk for en psykologiserende sosial diskurs. Den reflekterer en bevissthet om barn og unge som sårbare i et skoleregime som stiller store krav til måloppnåelse i fagene (og da særlig de teoretiske fagene), og som kontinuerlig minner elevene om at de selv har ansvar for å nå målene. De sosiale målene kan ses i sammenheng med den sosiale diskursen som framkommer i direkte henvendelser og hilsener, som gir uttrykk for at eleven har stor egenverdi som menneske, og at læreren synes det er fint å være sammen med ham/henne, slik som når det står: «Ha en super høstferie, alle sammen! Takk for en fin oppstart!» (5. trinn, skole 10), «Vi minner om Beintøft - å gå til skolen, uansett vær (-). Sunt for miljø, kropp og sjel!» (2. trinn, skole 9). På denne måten kan en si at den «myke» sosiale diskursen pakker inn den «harde» kunnskapsdiskursen, slik disse kommer fram i ukeplanen som tekst. Det er likevel de tydelige trekkene av sosial kontroll og selvdisiplinering som totalt sett blir stående som mest framtredende når de to diskursene ses samlet.

Det er interessant å se funnene i vår studie opp mot det Annerberg (2016) skriver om «diskursive vilkår» for læreres profesjonelle skriving (2016, se særlig kap. 8 og 9). Gymnaslærerne i hennes studie synes å være påvirket av ulike diskursive vilkår som påvirker deres profesjonelle skriving, og noen av disse vilkårene kan sies å stå i et motsetningsfylt forhold til hverandre. Annerberg viser til at det grunnleggende for lærernes skriving er et ønske om å arbeide effektivt og rasjonelt, men at dette ønsket om effektivitet samtidig er under press på grunn av økte dokumentasjonskrav. Lærernes profesjonsforståelse er knyttet til deres relasjon til mottakere av den enkelte teksten 
(som kan være mange ulike mottakerinstanser), men samtidig er de forpliktet til å dokumentere sin praksis for å legitimere denne og for å kunne forsvare valg som er gjort, overfor skoleledelse og sentrale myndigheter (Annerberg 2016, s. 279 ff.). Selv om Annerberg har gjort sin studie på bakgrunn av datamateriale knyttet til gymnaslæreres profesjonelle skrivepraksiser i Sverige, er det likevel et interessant bakteppe for vår studie, som er knyttet til 2., 5. og 7. trinn i den norske grunnskolen. Analysene av ukeplanen som sjanger kan bidra med et innblikk i hvordan lærere på detaljnivå forsøker å inngå i det vi har definert som to ulike diskurser samtidig, den kunnskapsbaserte og den sosiale. For begge disse diskursene synes ukeplanene å forsøke å balansere hensynet til ulike mottakere: på den ene siden eleven og hjemmet, og på den andre siden skoleledelse og øvrige styringsnivåer. Samtidig bidrar valgene av konkrete innholdselementer i meningsklyngene til å legitimere deres overordnede praksis knyttet til hver av de to diskursene, som vi har sett.

\section{Konklusjon}

Ukeplanen utgjør ikke den eneste kommunikasjonen mellom skole og hjem, men den er svært sentral på grunn av kontinuiteten den gjenspeiler. Det er derfor ikke uten betydning hvordan akkurat denne sjangeren kommuniserer hva skolen er og bør være, og hvilke krav og forpliktelser de ulike aktørene får eller har. For eksempel vil den for hjemmet kommunisere svært sterkt hva skolens arbeid består i, hva som vurderes, og hva som verdsettes. Slik vil den ha betydning også for andre kontaktpunkter mellom hjem og skole, som foreldremøter og utviklingssamtaler. Ukeplanen gir uttrykk for et kunnskapssyn som i stor grad er preget av nyliberal styringsideologi (New Public Management), med vektlegging av læring som håndfast produkt som kan måles og evalueres på ulike nivåer. Læreren designer lærearbeidet gjennom produksjonen av ukeplanen, og henvendelsesformer og bruk av modale hjelpeverb som «skal» og «må» stiller krav til både eleven og hjemmet. Det innebærer ansvarliggjøring og forpliktelser som både direkte og indirekte 
involverer hjemmet i mål- og resultatstyringsregimet - men på det laveste nivået, med minst makt og innflytelse. Samtidig kommuniserer ukeplanen at det også er et fellesskap mellom hjem og skole som tar sikte på å gi eleven grunnleggende verdier for det å være menneske - men denne diskursen framstår som en «hyggeliggjøring» av den viktigste diskursen, som er kunnskapsdiskursen. Disse to diskursene kan ses på som uttrykk for en verdikonflikt: en konflikt mellom økonomiverdenens produktorienterte verdier slik de gjenfinnes i New Public Management, og profesjonsverdiene som er vesentlige for lærerne i deres profesjonsutøvelse. Slik sett kan en si at ukeplanen som sjanger synliggjør kampen om handlingsrommet blant ulike aktører i utdanningssystemet. 


\section{Referanser}

Annerberg, A. (2016). Gymnaslärares skrivpraktiker: Skrivande som professionell handling $i$ en digitaliserad skola (doktoravhandling, Örebro Universitet). Hentet fra http://du.divaportal.org/smash/get/diva2:1050918/FULLTEXTo1.pdf 29.05.2018

Baldry, A. \& Thibault, P. (2006). Multimodal transcription and text analysis. London: Equinox.

Bergem, O.K. \& Dalland, C. (2010). Arbeidsplaner, læringsmål og vurdering: Hva gjør vi? Oslo: Universitetsforlaget.

Brown, R. \& Gilman, A. (1960). The pronouns of power and solidarity. I P.P. Giglioli (red.) (1972), Language and social context (s. 181-246).

Harmondsworth: Penguin.

Dalland, C. \& Bergem, O.K. (2010). Arbeidsplaner som alle forstår. Bedre Skole, nr. 4, 2010, 42-45.

Fairclough, N. (2010). Critical discourse analysis: The critical study of language. London: Routledge.

Fairclough, N. (2003). Analysing discourse: Textual analysis for social research. London: Routledge.

Gundersen, M.M. (2014). Hvordan kan skolen legge til rette for at foreldre og lærere kan samhandle mer om elevens læring? (masteravhandling $\mathrm{i}$ pedagogikk, NLA Høgskolen, Bergen). 
Hopfenbeck, T.N. (2011). Vurdering og selvregulert læring. Bedre Skole, nr. 4, 2011, 26-30. Lastet ned fra

https://www.utdanningsnytt.no/globalassets/filer/pdf-av-bedreskole/2011/bedre-skole-4-2011.pdf

Klette, K. (2007a). Arbeidsplaner som læringsverktøy - et hovedverktøy for å realisere tilpasset opplæring? Norsk Pedagogisk Tidsskrift, 91(4), 344-358.

Klette, K. (2007b). Arbeidsplaner som læringsverktøy - utfordringer og dilemmaer. Bedre Skole, nr. 4, 2007, 41-43.

Kress, G. \& van Leeuwen, T. (2006). Reading images: The grammar of visual design. London: Routledge.

Kvåle, G. (2018). Utdanningskvalitet som sakprosa: Evalueringstekster. Sakprosa, 10(2), 1-8.

Kvåle, G. (2012). Multimodalt samspill i bildeskriftkomplekser: En sosialsemiotisk undersøkelse av relasjoner mellom skrift og bilde (doktoravhandling; Doktoravhandlinger ved Universitetet i Agder 56).

Lærerprofesjonens etiske råd (2016). Lærerprofesjonens etiske plattform. Hentet fra https://static1.squarespace.com/static/57f7783b6b8f5b436ac8e7de/t/584853 8dd2b857115942864f/1481134992842/L\%C3\%A6rerprof etiske plattform 4 spr\%C $3 \%$ A 5 k.pdf.

Miller, C.R. (1994). Genre as social action. I A. Freedman \& P. Medway (red.), Genre and the New Rhetoric. London: Taylor and Francis. 
Møller-Nilsen, J.R. (2011). ... for dette er nye arbeidsredskaper for oss og ...: Foreldres erfaringer med elevens bruk av arbeidsplaner (masteroppgave i spesialpedagogikk, Universitetet i Stavanger).

Nordahl, T. (2007). Hjem og skole: Hvordan skape et bedre samarbeid? Oslo: Universitetsforlaget.

NUBU (2017). Hva er PALS? Hentet fra http://www.nubu.no/hva-erpals/category1129.html

Opplæringsloven. (1998). Lov om grunnskolen og den vidaregåande opplæringa. Oslo: Kunnskapsdepartementet.

Røn Larsen, M. (red.). (2014). Forældresamarbejde og inklusion. Lastet ned fra

https://pure.au.dk/ws/files/78787868/For_ldresamarbejdeOgInklusionMart s2014.pdf 29.05.2018

Sandvik, L.V. \& Buland, T. (red.). (2014). Vurdering i skolen: Utvikling av kompetanse og fellesskap. Sluttrapport fra prosjektet Forskning på individuell vurdering i skolen (FIVIS). Trondheim: NTNU.

Sandvik, L.V., Engvik, G., Fjørtoft, H., Langseth, I.D., Aaslid, B.E., Mordal, S. \& Buland, T. (2012). Vurdering i skolen - intensjoner og forståelser. Delrapport 1 fra prosjektet «Forskning på individuell vurdering i skolen» (FIVIS). Trondheim: NTNU Program for lærerutdanning og SINTEF

Todorov, T. (1990). Genres in discourse. Cambridge: Cambridge University Press.

Tønnessen, E.S. \& Vollan, M. (2010). Begynneropplæring i en sammensatt tekstkultur. Kristiansand: Høyskoleforlaget. 
Utdanningsdirektoratet (2006). Læreplanverket for Kunnskapsløftet. Hentet fra https://www.udir.no/laring-og-trivsel/lareplanverket/

Utdanningsdirektoratet. (2016a). Hva er hjem-skole-samarbeid? Hentet fra https://www.udir.no/kvalitet-og-kompetanse/samarbeid/hjem-skolesamarbeid/oversikt/

Utdanningsdirektoratet. (2016b). PISA (Programme for International Student Assessment) måler 15-åringers kompetanse i lesing, matematikk og naturfag. Hentet fra https://www.udir.no/tall-og-forskning/internasjonalestudier/pisa/ 